\title{
HUBUNGAN SIKAP IBU TERHADAP PENDIDIKAN SEKS DENGAN PEMBERIAN INFORMASI TENTANG SEKSUALITAS PADA PRA REMAJA PUTRI USIA 10-12 TAHUN
}

\author{
Aih Alawiyah Madjid, Tati S. D \& Nani N. Djamal \\ Fakultas Psikologi UIN Sunan Gunung Djati Bandung
}

\begin{abstract}
Parents are seen as role model and important figures in family whom responsible to teach and facilitate a suitable education model for their children. Children need many information and knowledge that would help them to solve all problems the face in their life. Pre adolescence children, especially young teenage girl in this case would need an appropriate sex education to help help them pass through their problems and social interaction life. This information was best given to them by mothers since children would felt safer with same sex beside this also could give other diversion about sexuality values adopted in society. Aside from it, there also a condition that many mothers felt that sex education was taboo and it was also caused by little information and knowledge those mothers had. At this point, mother's perception and parent's personal feeling have constructed a negative set of mind towards sex education

From this phenomenon, this research was conducted to analyze the correlation between mother's attitude towards sex education with information given and taught by them for young teenage girl between the age 10-12 years old. The datas gathered for this research were taken from sample of young teenage girls' mothers living at community housing complex in Tasikmalaya. The methods used in this research is correlational model which was used to analyze variables that caused the phenomenon and also try to find out the relationship between one variabel with another.

In this case study, we have made a specific assumptions to formulize a hypothese which then were tested to acquire a valid and reliable data from raw data using Spearman Rank's statistical analysis since both variables were ordinal and have a significancy level of 5 percent. Statistic analysis conducted in this research then resulted in correlation coefficient of 0,424 with an error margin of 0,003 - which means that the hypothese is accepted.

A brief conclusion that can be taken from this research is that parent's (mothers) educational background have great influence on their attitude toward sex education-which is-the higher the education those mothers had, the more positive they felt toward sex education.
\end{abstract}

Keywords: Sex education, pre adolescence

\section{Latar Belakang}

Kemajuan teknologi yang kian pesat dewasa ini berdampak positif dan negatif pada kehidupan. Proses kehidupan menjadi lebih mudah dengan hadirnya berbagai teknologi pembantu. Juga berkembangnya media komunikasi dan informasi yang memungkinkan manusia bisa berkomunikasi dan memperoleh informasi dengan mudah dan cepat.

Dampak negatif dari perkembangan media informasi kebanyakan menimpa anak- anak dan remaja. Remaja yang mempunyai ciri ingin tahu dan ingin mencoba, cenderung terpengaruh dan meniru pada yang dilihat dan didengar dari media-media tersebut. Maraknya bisnis penyewaan VCD dan internet serta munculnya tabloid atau majalah yang secara bebas menyajikan gambar-gambar porno memudahkan anak-anak dan remaja memperoleh informasi tentang seksual yang tidak selayaknya mereka konsumsi. Hal ini menstimulasi perilaku seksual yang lebih intens. Dari tahun ke 
tahun data remaja yang melakukan seks bebas semakin meningkat. Dari sekitar 5\% pada tahun 1980 menjadi 20\% pada tahun 2000 . Angka ini dikumpulkan dari berbagai penelitian yang diadakan di beberapa kota seperti Jakarta, Surabaya, Palu, dan Banjarmasin.

Sedangkan menurut lembar fakta yang diterbitkan PKBI, sekitar 2,3 juta kasus aborsi terjadi di Indonesia dan 20\% dilakukan oleh remaja. Sekitar $15 \%$ remaja usia 10 hingga 24 tahun di Indonesia yang jumlahnya mencapai 62 juta orang, telah melakukan hubungan seksual di luar nikah.

Fenomena tersebut tidak terlepas dari tata nilai kehidupan yang berlaku dalam masyarakat saat ini. Sebelum seorang anak mengenal lingkungan yang lebih luas, ia terlebih dahulu mengenal lingkungan keluarga. Oleh karena itu, sebelum ia mengenal nilainilai dan norma-norma dari masyarakat umum, pertama kali ia menyerap nilai dan norma yang berlaku dalam keluarganya untuk dijadikan bagian dari kepribadiannya (Sarwono, 1997).

Orangtua merupakan bagian utama dari keluarga dimana mereka memiliki tanggung jawab untuk memberikan arahan dan pendidikan kepada anak. Orangtua berperan membentuk perilaku anak melalui proses sosialisasi nilai-nilai, budaya, aturan, peran sosial dan budi pekerti (Newman, 1979). Sesuai usia, pada umumnya ibu memiliki anak pre-adolescent (pra remaja) ataupun adolescent (remaja) pada rentang usia 30-50 tahun (middle adulthood). Masa pra remaja merupakan masa paling berpengaruh dalam perkembangan seksual. Informasi seksual dibu- tuhkan pra remaja agar dapat mengurangi kebingungan jika terjadi perubahan seksual pada dirinya. Informasi seksual yang lebih dikenal dengan pendidikan seksual menyangkut pengetahuan mengenai kematangan seksual dan proses reproduksi yang bertujuan agar ketidakjelasan, perasaaan malu, dan perasaan terisolasi yang dialami anak ketika masa pubertas, dapat diminimalkan (Newman, 1975).

Pendidikan seks sebaiknya tidak diberikan secara terbuka melainkan secara kontekstual yaitu dalam kaitannya dengan normanorma yang berlaku dalam masyarakat, apa yang dilarang dan apa yang lazim serta bagaimana melakukannya tanpa melanggar aturan (Sarwono, 1997). Remaja sendiri mendambakan memperoleh informasi tentang seks dari orangtuanya (Sarwono, 1991). Dalam keluarga orangtualah yang berperan dalam pemberian informasi mengenai seks kepada anaknya secara benar dan terpercaya. Menurut penelitian Djaelani (Azwar, 1999), 94\% remaja menyatakan butuh nasehat mengenai seks. Namun sebagian besar remaja justru tidak dapat mengakses sumber informasi yang tepat. Jika mereka kesulitan untuk mendapatkan informasi melalui jalur formal, terutatama dari lingkungan sekolah maka kecendrungan yang muncul adalah coba-coba sendiri mencari sumber informal. Hal ini sangat menggugah rasa ingin tahu mereka untuk mencoba-coba dengan cara membahas bersama teman-teman, buku-buku tentang seks, atau mengadakan percobaan dengan masturbasi, bercumbu, atau berhubungan seksual (Hurlock, 1994). Menurut penelitian Zelnik \& Kim (1982), remaja 
Hubungan Sikap Ibu Terhadap Pendidikan Seks dengan Pemberian Informasi Tentang Seksualitas (Aih Alawiyah Madjid, Tati S. D, Nani N. Djamal)

putri yang belum pernah mendapatkan pendidikan seks cenderung lebih banyak mengalami kehamilan yang tidak dikehendaki.

Pada umumnya, pengaruh perubahan-perubahan seksual lebih banyak pada pra remaja putri dibanding pra remaja putra. Hal ini terjadi karena pra remaja putri biasanya lebih cepat matang daripada pra remaja putra. Selain itu juga karena hambatan-hambatan sosial mulai ditekankan pada perilaku pra remaja putri (Hurlock, 19-96). Hambatan-hambatan sosial tersebut di antaranya, tuntutan perilaku dengan membatasi diri terhadap lawan jenis, tampil lebih feminin agar terlihat sebagai wanita dewasa atau tuntutan harus menjaga kebersihan tubuhnya. Tuntutan-tuntutan tersebut terjadi karena pra remaja putri yang mengalami perubahan seksual ke arah kematangan fungsi seksual tersebut dianggap memiliki resiko lebih besar jika tidak dapat menjaga perilakunya seperti kehamilan yang tidak dikehendaki ataupun pemerkosaan.

Dalam situasi demikian, orangtua dapat memberikan informasi memadai yang diperlukan oleh kelompok pra remaja. Orangtua lebih merasa bertanggungjawab memberikan informasi dampak seks bebas pada pra remaja putri dibandingkan pra remaja putra dan kebanyakan tanggung jawab itu lebih dikembangkan oleh ibu daripada ayah (Sprinhal, 1995). Jadi dapat dikatakan ibu lebih bertanggung jawab untuk memberikan pendidikan seks karena ibu lebih mengerti perkembangan yang terjadi pada anak putri yang akan beranjak dewasa.
Di Indonesia masih banyak ibu yang belum memberikan pendidikan seks pada pra remaja putri. Faktor-faktor yang mempengaruh antara lain masih kurangnya keterampilan atau kemampuan ibu dalam mendekati dan mengkomunikasikan informasi seksual pada anak, masih kecilnya kesediaan ibu meluangkan waktu untuk berkomunikasi, masih kurangnya pengertian ibu tentang apa yang dibutuhkan oleh pra remaja putri serta masih banyak pihak-pihak yang memiliki perbedaan persepsi tentang pendidikan seks (Sarwono, 1997).

\section{Manfaat dan Tujuan Penelitian}

Tujuan dari penelitian ini adalah untuk memperoleh gambaran mengenai hubungan antara sikap ibu terhadap pendidikan seks dengan pemberian informasi tentang seksualitas pada pra remaja putri usia 10-12 tahun di komplek Argasari Kecamatan Cihideung Kabupaten Tasikmalaya.

Penelitian ini diharapkan dapat memberikan kegunaan antara lain:

1. Secara teoretis, hasil yang diperoleh dari penelitian ini diharapkan dapat menjadi sumber informasi dan pemahaman yang lebih mendalam mengenai berapa besar hubungan sikap ibu terhadap pendidikan seks dengan pemberian informasi tentang seksualitas pada pra remaja putri.

2. Secara praktis, hasil penelitian diharapkan dapat menjadi bahan pertimbangan bagi pihak orangtua pada khususnya, dan pada umumnya pihak lain yang tertarik pada masalah yang dialami para remaja khususnya perkembangan pra remaja putri usia 10-12 tahun. 


\section{Kerangka Berpikir}

Pra remaja adalah usia dimana seorang anak bergerak meninggalkan masa kanakkanaknya dan mulai memasuki masa remaja yang penuh dengan perubahan-perubahan, baik secara fisik, psikologis dan sosial. Dalam teori psikologi pekembangan yang termasuk usia pra remaja adalah anak-anak berusia sekitar 10 tahun hingga 12 tahun (Engel, 1999).

Pendekatan 'life span' menekankan pada pentingnya mempersiapkan seorang anak selama tahap perkembangan sebelumnya agar dia dapat menghadapi kejadian-kejadian yang mungkin terjadi pada tahap perkembangan berkutnya (Newman, 1975).

Dalam keadaan ini orangtua perlu untuk memberikan informasi atau pengetahuan mengenai masalah-masalah perkembangan seksual. Oleh karena itu, masa pra remaja adalah masa yang paling baik untuk memberikan informasi seksual. Sedangkan menurut Newman (1975) usia yang paling baik yang berkaitan dengan perubahan tubuh mereka terutama yang menyangkut memberikan informasi seksual adalah 8-12 tahun (middle school age). Informasi seksual ini akan dapat membantu mereka dalam menerima dan menyesuaikan diri dengan baik pada perubahan tubuh yang akan mereka alami pada masa remaja nanti.

Pemberian pendidikan seksual yang dibicarakan di sini adalah tentang proses reproduksi, perkembangan seksual manusia, tingkah laku seksual, perkawinan, hubungan seks, dan aspek-aspek kesehatan serta aspek psikososial (kejiwaan dan kemasyarakatan dari sek- sualitas) (Sarwono, 1986). Pendidikan seks juga diperlukan untuk menjembatani rasa keingintahuan pra remaja yang besar terhadap hal-hal yang berkaitan dengan masalah seksualitas dengan informasi tentang seksualitas yang benar, jujur, dan lengkap.

Pendidikan seks kepada pra remaja putri oleh orangtua sebaiknya disertai pengalihan nilai (Sarwono, 1986). Penelitian Fox \& Inazu (1980) membuktikan bahwa semakin sering terjadi percakapan tentang seksualitas antara ibu dengan anak putri atau ayah dengan anak putra maka tingkah laku seksualnya pun semakin bertanggung jawab (Sarwono, 1997).

Adapun untuk pra remaja putri usia 1012 tahun informasi seksual yang sebaiknya disampaikan adalah:

1. Perkembangan fisik secara umum, termasuk semua perkembangan tubuh

2. Perkembangan seksual termasuk organ seksual

3. Perkembangan emosi termasuk perubahan emosi

4. Perkembangan sosial, termasuk semua interaksi sosial, kebanyakan dengan teman sebaya tetapi juga dengan orang dewasa (Engel, 1997)

Menurut Fishbein \& Ajen (1975) salah satu faktor penting yang menjadi penentu sikap adalah keyakinan (belief). Artinya individu membentuk keyakinan terhadap suatu tingkah laku secara otomatis membentuk sikap terhadap tingkah laku tersebut. Jadi keyakinan ibu bahwa pemberian informasi masalah seksual yang tercakup dalam pendidikan seks akan berhasil-tidak berhasil, pantas-tidak pantas, 
Hubungan Sikap Ibu Terhadap Pendidikan Seks dengan Pemberian Informasi Tentang Seksualitas (Aih Alawiyah Madjid, Tati S. D, Nani N. Djamal)

perlu-tidak perlu, akan membentuk sikap terhadap pendidikan seks. Sikap menurut Rosenberg \& Hovland (1960) dalam Ajzen (1988) memiliki tiga komponen yaitu:

1. Kognitif, berisi keyakinan ibu mengenai apa itu pendidikan seks atau persepsi ibu tentang kegunaan pendidikan seks itu sendiri. Terdapat dua jenis respon dalam komponen kognitif yaitu respon verbal dan non verbal. Respon kognitif verbal adalah seberapa kepercayaan ibu tentang beberapa karakteristik/atribut pendidikan seks. Sedangkan respon kognitif non verbal adalah reaksi perseptual terhadap objek sikap, seperti banyaknya kehamilan di luar nikah membuat pendidikan seks penting bagi setiap pra remaja putri.

2. Afektif, menyangkut masalah emosional subyektif ibu terhadap pendidikan seks itu sendiri. Komponen afektif ini merupakan perasaan ibu terhadap pendidikan seks dan materinya, apakah suka-tidak suka, malu-tidak malu, canggung-tidak canggung, dalam memberikan pendidikan seks pada pra remaja. Komponen afektif ini diukur dari seberapa percayanya ibu pada pendidikan seks. Bila ibu percaya bahwa pendidikan seks itu sesuatu yang porno dan belum pantas diterima oleh putrinya, maka terbentuklah perasaan sungkan dan malu untuk menyampaikannya. Ungkapan rasa malu/sungkan merupakan respon afektif verbal. Sedangkan respon afektif non verbal dapat berupa jantung berdebar, keluarnya keringat dingin dan muka memerah ketika ibu menyampaikan pendidikan seks pada putrinya.

3. Konatif, menunjukkan bagaimana perilaku /kecenderungan perilaku yang ada dalam diri ibu berkaitan dengan pendidikan seks. Hal ini didasari oleh asumsi bahwa belief dan perasaan banyak mempengaruhi perilaku. Intensi dan kemauan ibu dalam memberikan pendidikan dan penjelasan mengenai segala sesuatu yang menyangkut seksualitas manusia merupakan respon verbal konatif ibu. Sedangkan tingkah laku ibu dalam memberikan pendidikan seks merupakan respon konatif non verbal.

Tiga komponen sikap yaitu kognitif, afektif, dan konatif, berinteraksi secara selaras dan konsisten. Apabila ketiga komponen ini tidak konsisten maka akan menimbulkan mekanisme perubahan sikap sehingga konsistensi itu akan tercapai kembali.

1. Pendidikan seksual dibutuhkan oleh anakanak sebelum mereka mengalami kematangan seksual (masa pra remaja) karena informasi yang tepat akan berguna bagi mereka agar dapat beradaptasi dengan baik terhadap perubahan yang terjadi pada masa pubertas.

2. Pendidikan seks lebih tepat diberikan oleh orangtua karena disertai norma/nilai agama ataupun norma/nilai yang berlaku di masyarakat.

3. Pendidikan seks untuk pra remaja putri sebaiknya diusahakan pemberiannya oleh ibu karena berjenis kelamin sama.

Berdasarkan kerangka pemikiran tersebut, dapat dibuatkan skema hubungan sikap ibu terhadap pendidikan seks dalam pemberian informasi tentang seksualitas bagi pra remaja putri seperti terlihat pada gambar 1 . 


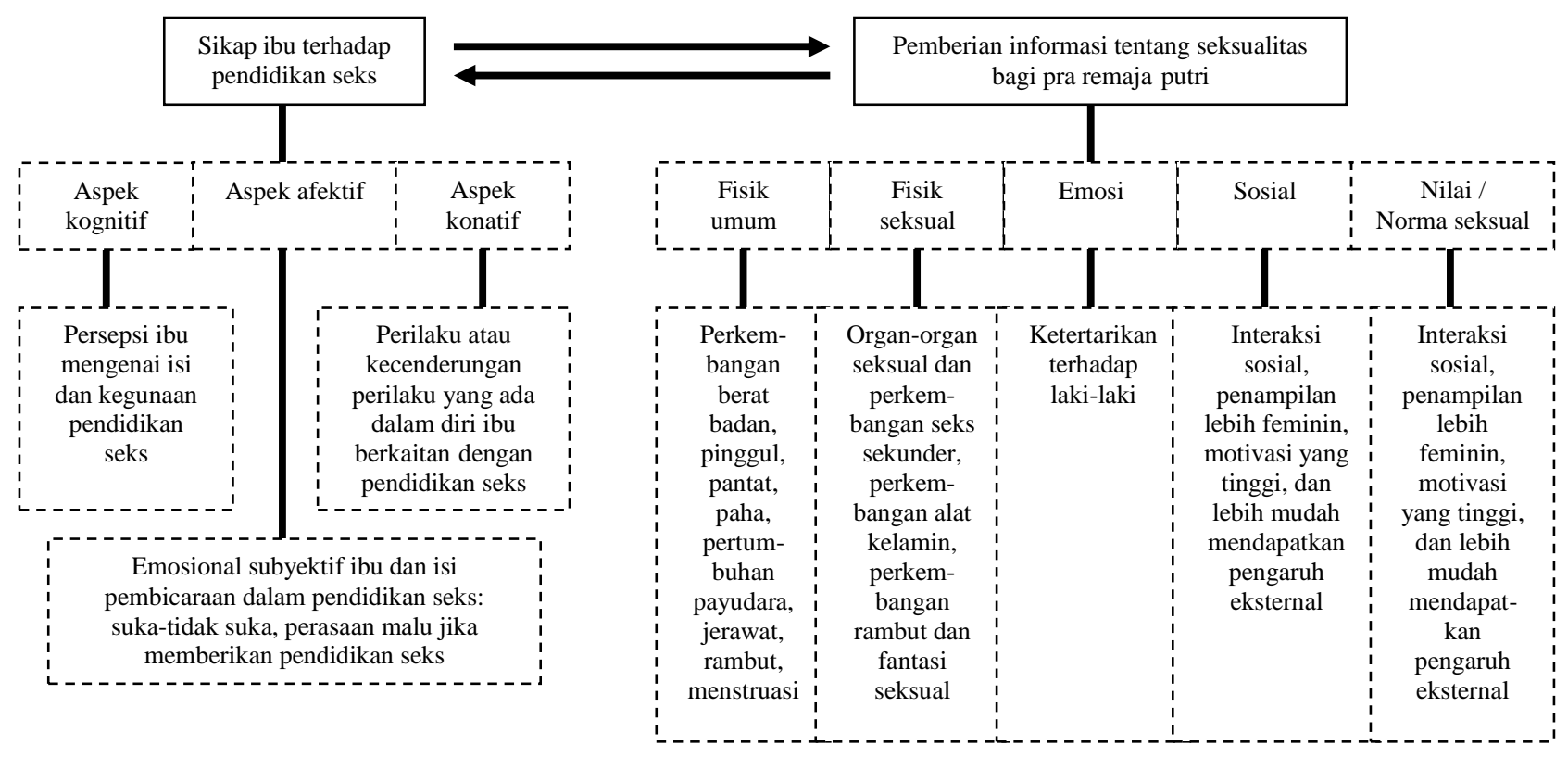

Gambar 1. Hubungan sikap ibu terhadap pendidikan seks dengan pemberian informasi tentang seksualitas

\section{Metode Penelitian}

Rancangan penelitian yang akan digunakan adalah penelitian korelasional. Metode ini dimaksudkan untuk menganalisa faktor-faktor penyebab terjadinya atau munculnya suatu fenomena tertentu serta menemukan bagaimana hubungan variabel pertama terhadap variabel kedua.

Dalam penelitian ini variabel yang akan diukur adalah sikap ibu terhadap pendidikan seks sebagai variabel pertama dan pemberian informasi tentang seksualitas sebagai variabel kedua. Secara operasional, sikap ibu terhadap pendidikan seks diartikan sebagai ungkapan kepercayaan, penghayatan emosional serta kecenderungan perilaku yang dimiliki subyek terhadap pendidikan seks. Semakin tinggi skor yang dicapai subyek berarti semakin positif sikap ibu terhadap pendidikan seks. Sebaliknya semakin rendah skor total maka semakin negatif sikap ibu terhadap pendidikan seks.
Secara operasional, pemberian informasi tentang seksualitas adalah diberikan atau tidaknya informasi tentang seksual oleh ibu kepada pra remaja putri. Hal ini dilihat berdasarkan skor total yang diperoleh responden dari skala pemberian informasi tentang seksualitas. Semakin tinggi skor total yang dicapai subyek menunjukkan semakin sering pemberian informasi seksual dan sebaliknya semakin rendah skor nilai menunjukkan pemberian informasi seksual yang semakin jarang.

\section{Subjek Penelitian}

Karakteristik subjek yang diperlukan dalam penelitian ini adalah:

a. Ibu-ibu usia 30-50 tahun mengingat rentang usia ini biasanya ibu memiliki anak gadis usia 10-12 tahun.

b. Mempunyai anak putri usia 10-12 tahun

c. Pendidikan minimal SMA. Batasan ini digunakan untuk mendapatkan homogenitas pengetahuan dalam pengisian kuesioner. 
d. Tinggal serumah dengan anak putrinya. Sehubungan dengan aktivitas keseharian anak putrinya agar bisa terkontrol oleh ibunya.

Populasi penelitian adalah ibu-ibu yang bertempat tinggal di komplek Argasari Tasikmalaya. Jumlah keseluruhan populasi adalah 46 orang. Kemudian diambil sampel sebanyak 27 orang secara acak.

\section{Alat Ukur}

Pengumpulan data dilakukan dengan alat pengumpul data berupa kuesioner yang terdiri dari skala. Terdapat dua macam skala yaitu skala sikap terhadap pendidikan seks dan skala pemberian informasi tentang seksualitas.

a. Skala sikap terhadap pendidikan seks

Skala ini dibuat berdasarkan teori Rosenberge \& Hovland (1960) dan diambil dari Sarlito (1997). Alat ukur ini terdiri dari tiga aspek yaitu aspek kognitif, afektif, dan konatif. Jumlah keseluruhan item adalah 84 item dengan 60 item positif dan 24 item negatif.

Pilihan jawaban pada skala sikap ini berkisar antara Sangat Setuju (SS), Setuju (S), Tidak Ada Pendapat (TAP), Tidak Setuju (TS), dan Sangat Tidak Setuju (STS). Skor diberikan dengan aturan berikut:

\begin{tabular}{|c|c|c|}
\hline $\begin{array}{c}\text { Alternatif } \\
\text { jawaban }\end{array}$ & $\begin{array}{c}\text { Nilai item } \\
\text { positif }\end{array}$ & $\begin{array}{c}\text { Nilai item } \\
\text { negatif }\end{array}$ \\
\hline SS & 5 & 1 \\
\hline S & 4 & 2 \\
\hline TAP & 3 & 3 \\
\hline TS & 2 & 4 \\
\hline STS & 1 & 5 \\
\hline
\end{tabular}

Tabel 1. Nilai sikap terhadap pendidikan seks b. Skala pemberian informasi tentang seksualitas

Skala ini dibuat berdasarkan teori Engel (1997). Alat ukur ini terdiri dari lima aspek, yaitu aspek pemberian informasi mengenai perkembangan fisik secara umum (9 item), pemberian informasi mengenai perkembangan fisik seksual (9 item), pemberian informasi mengenai perkembangan emosi ( 9 item), pemberian informasi mengenai perkembangan sosial (9 item), dan pemberian nilai atau norma seksual (11 item). Skala alat ukur ini memiliki pilihan jawaban yang berkisar antara selalu (Sl), sering (Sr), sekalisekali (Skl), jarang (Jr), dan tidak pernah (Tp). Skor diberikan dengan aturan berikut:

\begin{tabular}{|c|c|c|}
\hline $\begin{array}{c}\text { Alternatif } \\
\text { jawaban }\end{array}$ & $\begin{array}{c}\text { Nilai item } \\
\text { positif }\end{array}$ & $\begin{array}{c}\text { Nilai item } \\
\text { negatif }\end{array}$ \\
\hline $\mathrm{Sl}$ & 5 & 1 \\
\hline $\mathrm{Sr}$ & 4 & 2 \\
\hline $\mathrm{Skl}$ & 3 & 3 \\
\hline $\mathrm{Jr}$ & 2 & 4 \\
\hline $\mathrm{Tp}$ & 1 & 5 \\
\hline
\end{tabular}

Tabel 2. Nilai item pemberian informasi seksual

\section{Analisis Data \\ a. Analisa item}

Analisa item merupakan proses pengujian parameter-parameter item guna mengetahui apakah item memenuhi persyaratan psikometris untuk disertakan sebagai bagian dari skala atau tidak.

Kualitas sebuah skala ditentukan oleh kualitas itemnya. Sebuah skala yang berisi item berkualitas tinggi walaupun jumlahnya sedikit akan lebih berguna daripada sebuah skala yang berisi puluhan item berkualitas rendah. Item-item yang berkualitas rendah tidak saja akan menurunkan fungsi skala tetapi juga akan menghasilkan reliabilitas dan validitas yang rendah. 
Untuk skala psikologi yang mengukur atribut afektif, dalam seleksi item parameter yang paling penting adalah daya beda atau daya diskriminasi item, yaitu sejauhmana item mampu membedakan antara individu atau kelompok yang memiliki dan tidak memiliki atribut yang diukur. Indeks daya beda ini juga merupakan indikator keselarasan atau konsistensi antara fungsi item dengan fungsi skala secara keseluruhan yang dikenal dengan istilah korelasi item-total (itemtotal correlation $=\mathrm{r}_{\mathrm{ix}}$ ) yang disebut pula dengan parameter daya beda item. Formulasi korelasi yang digunakan dalam komputasi bergantung kepada sifat penskalaan (Azwar, 2003).

Dalam penelitian ini skala yang digunakan tidak dibobot sehingga level skala dianggap ordinal. Maka untuk menentukan indeks korelasi item-total digunakan formula Spearman's RankOrder Correlation Coefficient (Siegel, 1997: 250257), yaitu:

$$
r_{s}=1-\frac{6 \sum_{i=1}^{N} d_{i}^{2}}{N^{3}-N}
$$

Jika proporsi angka-sama pada kedua variabel besar, maka digunakan persamaan (2) yaitu:

$$
r_{s}=\frac{\sum x^{2}+\sum y^{2}-\sum d_{i}^{2}}{2 \sqrt{\sum x^{2} \sum y^{2}}}
$$

dimana:

$d_{i}$ : selisih antara dua ranking

$N$ : jumlah responden

$$
\begin{aligned}
& \sum x^{2}=\frac{N^{3}-N}{12}-\sum T_{x} \\
& \sum y^{2}=\frac{N^{3}-N}{12}-\sum T_{y}
\end{aligned}
$$

dengan $T=\frac{t^{3}-t}{12}$

$x$ dan $y$ : variabel-variabel yang akan dikorelasikan

$\mathrm{t}$ : banyak observasi yang berangka sama pada suatu ranking tertentu

Adapun langkah-langkahnya adalah sebagai berikut:

a. Mendaftar subyek dan skor-skor variabel yang akan dicari indeks korelasinya.

b. Memberi ranking untuk setiap subyek pada masing-masing variabel yang akan dicari indeks korelasinya.

c. Menentukan selisih (harga $d_{i}$ ) untuk setiap subyek dengan mengurangkan ranking variabel yang satu dengan ranking variabel yang lainnya.

d. Menguadratkan harga $d_{i}$ setiap subyek untuk mendapatkan harga $d_{i}^{2}$ kemudian harga-harga $d_{i}^{2}$ tersebut dijumlahkan.

e. Menentukan indeks korelasi $r_{s}$ dengan rumus 1, namun jika proporsi angka-sama pada variabel besar, maka gunakan rumus 2 dengan terlebih dahulu menentukan nilai $\Sigma x^{2}$ dan $\Sigma y^{2}$.

Nilai $r_{s}$ yang diperoleh dari per hitungan ini menunjukkan nilai daya beda item. Secara teoretis, makin tinggi koefisien korelasi positif antara skor item dengan skor skala, berarti makin baik kesesuaian antara item dengan keseluruhan skala. Sebagai kriteria pemilihan item, nilai daya beda item yang nilainya positif pada prinsipnya dapat digunakan, tetapi pada umumnya item yang memiliki indeks daya beda lebih dari atau sama dengan $0,3 \quad\left(\mathrm{r}_{\mathrm{ix}} \geq 0,3\right)$ dianggap memuaskan. Namun bila item yang 
Hubungan Sikap Ibu Terhadap Pendidikan Seks dengan Pemberian Informasi Tentang Seksualitas (Aih Alawiyah Madjid, Tati S. D, Nani N. Djamal)

lolos tidak mencukupi jumlah item yang diharapkan, peneliti dapat menurunkan batas kriteria (Azwar, 2002: 65).

\section{b. Uji reliabilitas}

Reliabilitas berarti keterpercayaan, kecermatan, atau konsistensi hasil pengukuran dari waktu ke waktu. Dalam pelaksanaannya reliabilitas dinyatakan oleh koefisien reliabilitas $\left(\mathrm{r}_{\mathrm{xx}}\right)$ yang angkanya berada pada rentang 0 -1.Semakin mendekati 1 berarti semakin tinggi reliabilitas alat ukur.

Data untuk menghitung koefisien reliabilitas diperoleh dari hasil penyajian satu set skala yang dikenakan hanya sekali saja pada sekelompok responden saat uji coba. Oleh karena itu, metode pengujian reliabilitas yang digunakan adalah metoda Split-half Reliability, yaitu nilai reliabilitas skala ditentukan dengan mencari indeks korelasi antara variabel jumlah skor tiap individu pada itemitem ganjil dan variabel jumlah skor tiap individu pada item-item genap. Untuk menentukan indeks korelasi ini karena level skalanya ordinal maka digunakan Rank-Order Correlation Coefficient dari Spearman dengan rumus dan langkah-langkah seperti penentuan indeks korelasi pada analisis item. Indeks korelasi Split-half ini dikoreksi dengan rumus Spearman-Brown Prophesy berikut:

$$
r_{b}=\frac{(N)\left(r_{l}\right)}{1+(N-1)\left(r_{l}\right)}
$$

dimana

$N=2$

$r_{b}$ : indeks korelasi hasil koreksi

$r_{l}$ : indeks korelasi Rank-Spearman c. Uji validitas

Pengujian validitas alat ukur diperlukan guna mengetahui apakah alat ukur, dalam penelitian ini berupa skala, mampu menghasilkan data yang akurat sesuai dengan tujuan ukurnya atau tidak. Karena hanya didapatkan satu set skor, maka untuk menguji validitas skala digunakan prosedur pengujian validitas konstruk dengan mencari indeks korelasi antara skor masingmasing faktor atau aspek skala dengan skor total skala (Djatmika, 1998: 28). Karena skor total skala dan skor masing-masing faktor berskala ordinal, maka untuk menentukan indeks korelasi tersebut digunakan Rank-Order Correlation Coefficient dari Spearman. Adapun rumus dan langkah-langkahnya sama dengan analisa item, hanya saja berbeda dalam variabelnya. Dalam hal ini variabel yang akan dicari indeks korelasinya adalah skor masing-masing faktor atau aspek skala dengan skor total skala.

Tidak ada batasan baku tentang angka minimal yang harus dipenuhi agar suatu skala dianggap valid. Kriteria umum yang digunakan adalah standar Guilford seperti berikut:

\begin{tabular}{|c|c|}
\hline $\begin{array}{c}\text { Interval } \\
\text { koefisien }\end{array}$ & Tingkat hubungan \\
\hline$<0,20$ & Tidak ada korelasi \\
\hline $0,20-0,40$ & Korelasi rendah \\
\hline $0,40-0,70$ & Korelasi sedang \\
\hline $0,70-0,90$ & Korelasi tinggi \\
\hline $0,90-1,00$ & Korelasi tinggi sekali \\
\hline 1,00 & Korelasi sempurna \\
\hline
\end{tabular}

Tabel 3. Kriteria koefisien reliabilitas Guilford 
4. Uji Statistik

a. Hipotesis statistik

Untuk melakukan uji statistik terhadap hipotesis yang telah diajukan, maka diturunkan hipotesis statistik se-bagai berikut:

$H_{0}: r_{s}=0$

Tidak terdapat hubungan antara sikap ibu terhadap pendidikan seks dengan pemberian informasi tentang seksualitas pada pra remaja putrinya

$$
H_{1}: r_{s} \neq 0
$$

Terdapat hubungan antara sikap ibu terhadap pendidikan seks dengan pemberian informasi tentang seksualitas pada pra remaja putrinya

b. Analisa uji korelasi

Seperti telah dikemukakan sebelumnya bahwa peneliti menggunakan correlational research method. Karena data berskala ukur ordinal maka digunakan statistik uji Rank Spearman. Formulasi dan langkah-langkah untuk perhitungannya sama seperti yang sudah dijelaskan pada bagian analisa item. Sedangkan uji signifikansi untuk menerima atau menolak $H_{0}$ dilakukan dengan uji student seperti berikut:

$$
t=r_{s} \sqrt{\frac{n-2}{1-r_{s}^{2}}}
$$

Kriteria uji untuk penolakan $H_{0}$ adalah

$$
t_{\text {hitung }} \geq t_{\text {tabel }}
$$

Atau jika perhitungan dilakukan dengan bantuan SPSS maka kriteria ujinya adalah:

$$
p_{\text {value }} \leq \alpha
$$

Untuk mengetahui besarnya kontribusi variabel tentang sikap ibu terhadap pendidikan seks dengan pemberian informasi tentang seksualitas bagi pra remaja putri maka dihitung nilai koefisien determinasi dengan formulasi berikut:

$d=r_{s}^{2} \times 100 \%$

Perhitungan statistik penunjang adalah statistik deskriptif yang menggambarkan keadaan variabel-variabel yang diukur dalam penelitian ini.

\section{Hasil Penelitian}

\section{Statistik Deskriptif}

Perhitungan deskriptif diawali dengan aturan pengelompokkan skor total setiap variabel untuk setiap kategori.

a. Variabel sikap terhadap pendidikan seks.

Hasil analisa item pada alat ukur sikap memberikan 84 item yang layak pakai dengan skor masing-masing item 1-5. Kategorisasi ditentukan dengan skor total minimum yang mungkin muncul adalah 77 dan skor total maksimum adalah 385. Diperoleh rentang untuk setiap kategori sebesar 102. Perhatikan tabel berikut:

\begin{tabular}{|c|c|c|}
\hline Variabel & Rentang & Kategori \\
\hline Sikap & $77-179$ & Sikap negatif \\
\cline { 2 - 3 } $\begin{array}{c}\text { terhadap } \\
\text { Pendidikan seks }\end{array}$ & $180-282$ & Sikap netral \\
\cline { 2 - 3 } & $283-385$ & Sikap positif \\
\hline
\end{tabular}

Tabel 4. Kategori sikap terhadap pendidikan seks Sumber:Hasil Pengolahan Data Penelitian

Sedangkan persentase responden untuk kategori sikap ini adalah sebagai berikut:

\begin{tabular}{|c|c|}
\hline Kategori & Persentase \\
\hline Sikap negatif & $10,87 \%$ \\
\hline Sikap netral & $86,96 \%$ \\
\hline Sikap positif & $2,17 \%$ \\
\hline
\end{tabular}

Tabel 5. Persentase responden dalam hal sikap terhadap pendidikan seks

Sumber:Hasil Pengolahan Data Penelitian 
b. Variabel pemberian informasi mengenai pendidikan seks

Hasil analisa item pada alat ukur pemberian informasi mengenai seksualitas memberikan 47 item yang layak pakai dengan skor masing-masing item 1-5. Kategorisasi ditentukan dengan skor total minimum yang mungkin muncul adalah 21 dan skor total maksimum adalah 105. Diperoleh rentang untuk setiap kategori sebesar 28. Perhatikan tabel berikut:

\begin{tabular}{|c|c|c|}
\hline Variabel & Rentang & Kategori \\
\hline Pemberian & $21-48$ & Tidak pernah \\
\cline { 2 - 3 } $\begin{array}{c}\text { Informasi } \\
\text { seksualitas }\end{array}$ & $49-76$ & Jarang \\
\cline { 2 - 3 } & $77-105$ & Sering \\
\hline
\end{tabular}

Tabel 6. Kategori pemberian informasi seksualitas Sumber:Hasil Pengolahan Data Penelitian

Sedangkan persentase responden untuk kategori pemberian informasi seksualitas ini adalah sebagai berikut:

\begin{tabular}{|c|c|}
\hline Kategori & Persentase \\
\hline Jarang & $13,04 \%$ \\
\hline Sering & $86,96 \%$ \\
\hline
\end{tabular}

Tabel 7. Persentase responden dalam hal pemberian informasi seksualitas

Sumber:Hasil Pengolahan Data Penelitian

\section{c. Analisa Uji Korelasi}

Hasil pengujian hipotesis penelitian menggunakan analisa korelasi Rank Spearman dapat dilihat pada tabel 8. Dari tabel ini dapat disimpulkan bahwa hipotesis penelitian dapat diterima dengan tingkat signifikansi 5\% karena data menghasilkan nilai peluang kekeliruan 0,003 . Artinya masih berada di bawah ambang batas kekeliruan yang diperbolehkan yaitu sebesar 0,05 .

\begin{tabular}{|c|l|r|r|}
\hline & & Sikap & \multicolumn{1}{c|}{ PIS } \\
\hline Sikap & Spearman's rho & 1 & .424 \\
& Sig.(2-tailed) & & .003 \\
& N & 46 & 46 \\
\hline PIS & Spearman's rho & .424 & 1 \\
& Sig.(2-tailed) & .003 & \\
& N & 46 & 46 \\
\hline
\end{tabular}

Correlation is significant at the 0.01 level (2-tailed)

Tabel 8. Hasil korelasi antara sikap terhadap pendidikan seks dengan pemberian informasi seksualitas (PIS)

Sumber:Hasil Pengolahan Data Penelitian

Koefisien korelasi sebesar 0,424 ini tergolong sedang menurut Guilford.

Selanjutnya hasil analisa hubungan variabel sikap terhadap pendidikan seks beserta dimensi-dimensinya yaitu dimensi kognitif, afektif, dan konatif terhadap variabel perilaku pemberian informasi seksualitas yang memiliki lima dimensi yaitu: dimensi pemberian informasi mengenai perkembangan fisik secara umum, perkembangan fisik seksual, perkembangan emosi, perkembangan sosial, dan perkembangan nilai atau norma.

d. Hubungan sikap terhadap dimensi-dimensi pemberian informasi seksualitas

\begin{tabular}{|c|c|c|c|}
\hline \multicolumn{4}{|c|}{ Correlation } \\
\hline & \multicolumn{3}{|c|}{ Sikap } \\
\hline \multirow[t]{5}{*}{$\begin{array}{c}\text { Spearman's } \\
\text { rho }\end{array}$} & Fisik umum & $\begin{array}{l}\text { Correlation } \\
\text { coefficient } \\
\text { Sig.(2-tailed) } \\
\mathrm{N}\end{array}$ & $\begin{array}{r}0,30 \\
0,05 \\
46\end{array}$ \\
\hline & Fisik seks & $\begin{array}{l}\text { Correlation } \\
\text { coefficient } \\
\text { Sig.(2-tailed) } \\
\mathrm{N}\end{array}$ & $\begin{array}{r}0,37 \\
0,01 \\
46 \\
\end{array}$ \\
\hline & $\begin{array}{c}\text { Perkembang } \\
\text { an emosi }\end{array}$ & $\begin{array}{l}\text { Correlation } \\
\text { coefficient } \\
\text { Sig.(2-tailed) } \\
\mathrm{N}\end{array}$ & $\begin{array}{r}0.30 \\
0,04 \\
46 \\
\end{array}$ \\
\hline & $\begin{array}{c}\text { Perkembang } \\
\text { an sosial }\end{array}$ & $\begin{array}{l}\text { Correlation } \\
\text { coefficient } \\
\text { Sig. }(2 \text {-tailed) } \\
\mathrm{N}\end{array}$ & $\begin{array}{r}0.37 \\
0,01 \\
46 \\
\end{array}$ \\
\hline & Norma & $\begin{array}{l}\text { Correlation } \\
\text { coefficient } \\
\text { Sig.(2-tailed) } \\
\mathrm{N}\end{array}$ & $\begin{array}{r}0,19 \\
0,21 \\
46 \\
\end{array}$ \\
\hline
\end{tabular}

Tabel 9. Hasil korelasi sikap terhadap dimensi pemberian informasi seksualitas

Sumber:Hasil Pengolahan Data Penelitian 
Dari tabel di atas tampak korelasi sikap terhadap pendidikan seks berhubungan signifikan dengan dimensi-dimensi dalam pemberian informasi mengenai pendidikan seks yaitu dimensi fisik secara umum, dimensi fisik mengenai seks, dimensi perkembangan emosi dan dimensi perkembangan sosial yang masing-masing memiliki koefisian korelasi sebesar 0,30, 0,37, 0,30 dan 0,37. Menurut Guilford dimensi-dimensi pemberian informasi mengenai pendidikan seks tersebut berhubungan dengan sikap terhadap pendidikan seks dengan kadar rendah. Kecuali terhadap dimensi norma variabel sikap terhadap pendidikan seks tidak memiliki hubungan yang signifikan.

e. Hubungan dimensi-dimensi sikap terhadap pemberian informasi seksualitas

\begin{tabular}{|c|c|c|r|}
\hline \multicolumn{3}{|c|}{ Correlation } \\
\hline \multirow{4}{*}{$\begin{array}{c}\text { Spearman's } \\
\text { rho }\end{array}$} & Kognisi & $\begin{array}{c}\text { Correlation } \\
\text { coefficient }\end{array}$ & 0,27 \\
& & Sig.(2-tailed) & 0,07 \\
& & N & 46 \\
\cline { 2 - 4 } & Afeksi & Correlation & 0,32 \\
& & coefficient & \\
& & Sig.(2-tailed) & 0,03 \\
& & N & 46 \\
\cline { 2 - 4 } & Konasi & Correlation & 0.38 \\
& & coefficient & \\
& & Sig.(2-tailed) & 0,01 \\
& & 46 \\
\hline
\end{tabular}

Tabel 10. Hasil korelasi dimensi sikap terhadap pemberian informasi tentang seksualitas Sumber:Hasil Pengolahan Data Penelitian

Dari tabel tersebut dapat disimpulkan terdapat dua dimensi dalam variabel sikap terhadap pendidikan seks yang menunjukkan hubungan yang signifikan dengan variabel pemberian informasi mengenai pendidikan seks, yaitu dimensi afeksi dan konasi. Dimensi afeksi memiliki keeratan hubungan dengan pemberian informasi mengenai seks sebesar 0.32 yang tergolong hubungan yang lemah. Hubungan yang lemah terhadap pemberian informasi mengenai seks dijumpai terhadap dimensi konasi yaitu sebesar 0.38. Sedangkan pemberian informasi mengenai seks tidak berhubungan signifikan dengan dimensi kognisi, karena tidak memiliki tingkat signifikasi yang lebih besar dari taraf nyata $\alpha=5 \%$. Untuk dimensi-dimensi sikap yang menunjukkan hubungan yang signifikan terhadap pemberian informasi mengenai seks memiliki tingkat signifikasi yang lebih kecil dari $\alpha=5 \%$ yaitu masing-masing sebesar 0,03 dan 0,01 .

\section{Simpulan dan Saran}

1. Simpulan

Dari analisa hasil penelitian tentang hubungan sikap ibu terhadap pendidikan seks dengan pemberian informasi tentang seksualitas pada pra remaja putri usia 10-12 tahun dapat ditarik beberapa kesimpulan, yaitu:

a. Hipotesis penelitian diterima. Artinya semakin positif sikap ibu terhadap pendidikan seks maka pemberian informasi seksualitas pun semakin sering. Sebaliknya semakin negatif sikap ibu terhadap pendidikan seks maka pemberian informasi seksualitas pun semakin jarang.

b. Sikap ibu terhadap pendidikan seks terbukti secara construct validity dapat diwakili oleh dimensi-dimensi sikap yaitu kognitif, afektif, dan konatif. Latar belakang pendidikan ibu cenderung mempengaruhi sikap ibu terhadap pendidikan seks. Ibu yang berpendidikan tinggi (sarjana) 
cenderung memiliki sikap positif terhadap pendidikan seks.

c. Pemberian informasi seksual pada pra remaja putri usia 10-12 tahun secara construct validity terbukti dapat diwakili oleh lima dimensi yaitu pemberian informasi mengenai perkembangan fisik umum, seksual, emosi, sosial, dan nilai/norma seksualitas. Dari data diketahui bahwa informasi yang sering diberikan pada pra remaja putri usia 10-12 tahun adalah informasi mengenai perkembangan fisik umum dan fisik seksual. Sedangkan informasi mengenai nilai atau norma dianggap cukup didapatkan dari sekolah atau pengajian.

2. Saran

Data dan pembahasan pada penelitian ini dapat berguna secara praktis dan menjadi langkah awal masukan bagi penelitian selanjutnya. Saran bagi penelitian lanjutan adalah:

a. Tampaknya para ibu masih merasa tabu memberikan informasi perkembangan seksual. Karena itu sebaiknya diteliti lebih jauh perbandingan pengaruh pemberian informasi seksual oleh ibu dan oleh ahli.

Populasi penelitian ini terbatas. Karena itu generalisasi yang luas dari hasil penelitian kurang dapat dilakukan. Untuk penelitian lanjut dapat diperluas cakupan wilayahnya.

\section{Daftar Pustaka}

Ajen, Icek. (1988). Attitudes, personality, and behavior. Milton Key-nes. Open University Press.
Azwar, Saepudin. (1995). Sikap manusia : teori dan pengukurannya. Edisi 2. Yogyakarta: Pustaka Pelajar.

Azwar, Saepudin. (1999). Penyusunan Skala Psikologi. Edisi 1. Yogya-karta: Pustaka Pelajar.

Engel, B. (1997). Beyondthe Birds and the Bees: Fost erring your child's Healthy Sexual Development. Pockt Book. New York.

Fishbein, M\&Ajen. I. (1975). Belief Attitude, intention, \& behavior : an introduction to theory \& research. Massachcusset. Addison westey publishing company.

Hurlock, EB. (1996). Asas-Asas Psikologi Perkembangan. Suatu pendekatan sepanjang rentang kehidupan. Edisi 5. Jakarta: PT Erlangga.

Nazir, Mohamad (1998). Metode penelitian. Edisi 3. Jakarta: Galia Indonesia

Newman, Barbara M. \& Philip R. (1975). Development Through life. Lionis: The Dorsex Press Home wood.

Sarwono, Sarlito. (1997). Psikologi remaja. Edisi 1. Jakarta: CV Rajawali Jakarta

Sarwono, Sarlito. (1991). Teori-teori Psikologi sosial. Jakarta: CV Rajawali Jakarta

Sarwono - Dra Pratiwi. (2000). Pendidikan seks untuk remaja. Jogjakarta: PT Tugu Publisher.

Sarwono, Sarlito - Siamidar, Ami (1986). Peran orangtua dalam pendidikan seks. Edisi 1. Jakarta: CV Rajawali Jakarta

Siegel, Sidney. (1997). Statistik Nonparametrik untuk Ilmu-ilmu Sosial. Terjemahan Zanzawi Suyuti \& Landung Simatupang. Jakarta: Gramedia Pustaka.

Sudjana, N. (1996). Metode Statistika. Edisi 5. Bandung: PT Tarsito.

Sprinhall, Norman \& Collins, W. Andrew (1995). Adolescent Psychology. Development View. New York : Mc GrawHill

Subino (1987). Konstruksi dan analisa tes. Jakarta: Departemen pendidikan dan kebudayaan. 
Psympathic, 2009, Vol. I, No.1: 73-86 